\title{
РОЛЬ ВИКЛАДАЧА ВНЗ У ЗАБЕЗПЕЧЕННІ ПОТРЕБ СТУДЕНТІВ У ЗДОРОВОМУ СПОСОБІ ЖИТТЯ
}

Швець Н. А. Роль викладача ВНЗ у забезпеченні потреб студентів у здоровому способі життя.

У статті висвітлено педагогічні умови, що забезпечують ефективне формування здорового способу життя студентів в освітньому процесі вишу. Розкрито внутрішні і зовнішні чинники, що зумовлюють мотивацію студентів до здорового способу життя. Розглянуто основні цільові установки програмнометодичного забезпечення формування здорового способу життя студентської молоді та принципи побудови освітнього процесу.

Ключові слова: забезпечення здорового способу життя, студентська молодь, суспільство, педагогічні умови, молоде покоління, спосіб життя, мотивація студентів.

Швец Н. А. Роль преподавателя вуза в обеспечении потребностей студентов в здоровом образе жизни.

В статье освещаются педагогические условия, обеспечивающие эффективное формирование здорового образа жизни студентов в образовательном процессе вуза. Раскрываются внутренние и внешние факторы, обуславливающие мотивацию студентов к здоровому образу жизни. Рассматриваются основные целевые установки программно-методического обеспечения формирования здорового образа жизни студенческой молодежи и принципы построения образовательного процесса.

Ключевые слова: Формирование здорового образа жизни, студенческая молодежь, общество, педагогические условия, молодое поколение, образ жизни, мотивация студентов.

Shvets N. A. The role of a university teacher in providing for the needs of students in a healthy lifestyle.

The work highlights the pedagogical conditions, to ensure effective formation of a healthy way of life among students in the educational process of the university. Disclosed internal and external factors responsible for the motivation of students to a healthy lifestyle. Considered are the main targets of methodical software for formation of healthy lifestyle of the student youth, and principles of the educational process.

Key words: Formation of a healthy way of life, students, society, pedagogical conditions, the younger generation, lifestyle, motivation of the students.

Здоров'я людини розглядається як філософська, соціальна, економічна, біологічна, медична категорії, об'єкт споживання, додатковий капітал, індивідуальна і суспільна цінність, явище системного характеру, динамічне, постійно взаємодіюче 3 навколишнім середовищем.

Науковцями різних галузей науки (медицини, педагогіки, психології, філософії, соціології) обгрунтовуються визначення та підходи до понять «здоров'я» та «здоровий спосіб життя». Тривалий час ми сприймали вислів: «У здоровому тілі - здоровий дух» як аксіому, але життя доводить, що взаємозв'язки духу і тіла значно складніші. Перефразовуючи це висловлювання, дозволимо сформулювати основну думку: «Зробимо все, щоб здоров’я стало категорією педагогічною». 
Аналіз психолого-педагогічних напрацювань вітчизняних та зарубіжних дослідників засвідчує, що в теорії та практиці вищої освіти накопичено значний науковий і прикладний потенціал, який може стати основою для вдосконалення підходів до забезпечення здорового способу життя студентської молоді. Так, розробленням теоретико-методичних основ підготовки студентів до здорового способу життя у навчальних закладах опікувались О. Біда, О. Дубасенюк, А. Линенко, О. Пехота, Л. Таланова, Г. Троцко, Л. Хомич, В. Шиян; вивчали досвід формування здорового способу життя молоді в зарубіжних країнах Н. Абашкіна, М. Лещенко, Л. Пуховська; проблему професійно-педагогічної готовності студентів вищих навчальних закладів до використання нових технологій у забезпеченні здорового способу життя досліджували О. Березюк, І. Зязюн, Н. Клокар, В. Ковальчук, Н. Нетребко, Т. Солодка. Однак питанню ролі викладача у забезпеченні потреби в здоровому способі життя студентської молоді не приділено належної уваги.

Mema cmammi - висвітлити роль викладача ВНЗ у забезпеченні потреби у здоровому способі життя студентської молоді, що має важливе значення для духовного, розумового, фізичного розвитку і виховання особистості студента.

Роль викладача вищої школи має соціальне значення і посідає одне 3 центральних місць у формуванні національної свідомості й духовної культури суспільства. Викладач вищого навчального закладу - це активний соціальний діяч, який здійснює свідомо керовану, цілеспрямовану та організовану соціалізацію студентів, їхнє виховання та навчання. Професійна діяльність педагога - це духовний, інтелектуальний і культурний потенціал, що дозволяє розвивати студента як особистість. Така важливість ролі педагога та результатів його діяльності зумовлює відповідні високі вимоги як до особистості, так i до професійної майстерності викладача.

Викладач не тільки надає студентам певну сукупність знань, він розвиває його самостійність, формує критичне мислення, уміння виробляти власну точку зору. Ефективність та сила впливу на емоції і свідомість студентів певною мірою залежить від особистості самого викладача. Зауважимо, що діяльність викладача спрямована не лише на організацію навчально-пізнавального процесу, а й на організацію навчальної, виховної діяльності студентів, систематичне розв'язання нових завдань, зокрема формування рис активного громадянина. При цьому головним завданням викладача $\epsilon$ не тільки якісне викладання дисципліни й передача студентам необхідних знань, умінь, навичок зі свого предмета, а й сприяння культу здоров'я, активне пропагування здорового способу життя здорових громадян держави. Вихованість і рівень освітньої підготовки, особистісне ставлення викладача до проблем дотримання здорового способу життя проектується на студентську молодь і $є$ прикладом для наслідування. У зв'язку з цим потрібно зауважити, що викладач ВНЗ є не тільки носієм змісту освіти, який створює педагогічні умови, що забезпечують результативність у збереженні потреби студентів у здоровому способі життя, але й має бути особистістю, здатною зацікавити студентів, професіоналом високого рівня, що володіє знаннями про новітні досягнення психолого-педагогічної науки, методами самостійного здобуття й засвоєння цих знань, новим педагогічним мисленням, моделює навчальні технології відповідно до цілей освіти.

Діяльність викладача, пов'язана 3 забезпеченням потреби студентів у здоровому способі життя, у вищому навчальному закладі має грунтуватися на системному підході, що передбачає участь у ній усіх суб'єктів навчально-виховного процесу. Ця діяльність спрямована на фізіопсихосоціальну адаптацію студентів 
шляхом спеціально розробленого змісту навчально-виховної роботи, а також методів і засобів іiі реалізації. Відповідно, така робота передбачає забезпечення умов фізичного, психічного, соціального i духовного комфорту, що сприяє збереженню та зміцненню здоров’я суб'єктів освітнього процесу, їхній продуктивній навчально-пізнавальній і практичній діяльності, яка грунтується на науковій організації праці та культурі здорового способу життя особистості [2, c. 115].

Отже, професійна діяльність викладача у вищій школі, спрямована на забезпечення потреби студентської молоді у здоровому способі життя, - складне, поліфункціональне соціальне явище з управління процесом здоров'язбереження, що передбачає впровадження еколого-гігієнічних, психовалеологічних, медиковалеологічних, оздоровчо-розвивальних, психологічних, фізкультурно-оздоровчих та інших здоров'язбережувальних методик у навчально-виховний процес, які не перешкоджають, а сприяють зміцненню і збереженню здоров'я, спрямовані на формування здоров'язбережувального освітнього середовища.

Процес підготовки студентів до ведення здорового способу життя у вищій школі становить багатоаспектну систему, основними функціями якої, як стверджує I. Краснов, є такі: накопичення знань (наукові дослідження в галузі охорони здоров'я, упровадження їх у практику; розроблення нових навчальних дисциплін та освітніх програм здоров'язбережувального спрямування, науково-методичний супровід); передавання знань (навчальний процес у розмаїтті форм, методів, засобів і освітніх технологій); поширення знань (видання навчальних посібників, наукових монографій, статей; виступи перед громадськістю, участь у наукових, навчальнометодичних і культурно-просвітницьких заходах регіонального, всеросійського i міжнародного рівнів із проблем збереження здоров'я та забезпечення здорового способу життя); формування в того, хто навчається, уміння й усвідомлення необхідності навчатися здорового способу життя впродовж усього життя [4, с. 63].

Поділяємо думку про те, що цими функціями визначаються головні складники викладацької діяльності: науково-предметний, психолого-педагогічний, культурнопросвітницький.

На думку О. Вольнської та І. Краснова, до викладача вищої школи задля забезпечення потреби студентів у здоровому способі життя ставляться такі вимоги: 1) висока професійна компетентність - глибокі знання й широка ерудиція в науково-предметній галузі, нестандартне мислення, креативність; 2) педагогічна компетентність - знання педагогіки і психології, медицини, валеології, володіння сучасними формами, методами, засобами й технологіями навчання; 3) комунікативна компетентність - культура мовлення, володіння сучасними інформаційними технологіями, ефективними методами й прийомами міжособистісного спілкування; 4) соціально-економічна компетентність - знання глобальних процесів розвитку цивілізації та функціонування сучасного суспільства, а також основ соціології, екології, економіки і права [3].

До цього варто додати і високий рівень культури здоров'я викладача, сформований науковий світогляд, стійку систему національних і загальнолюдських духовно-моральних цінностей.

Слід зауважити, що основними напрямами роботи викладачів із забезпечення потреби студентів у здоровому способі життя є:

- формування стійкої мотивації до здорового способу життя, що передбачає: урахування інтересів, потреб і мотивів студентів, формування позитивних емоцій, розвиток елементарних навичок 3 охорони здоров'я, початкових санітарно- 
гігієнічних умінь. Ефективність процесу забезпечення позитивної мотивації на здоровий спосіб життя залежить від спрямованості навчально-виховного процесу. Роль викладача полягає в тому, щоб через форми, методи організації навчання (бесіда, диспут, лекція, семінар, соціальне проектування, метод відкритої трибуни, ситуаційно-рольова гра, соціально-психологічний тренінг, інтелектуальний аукціон, «мозкова атака», метод аналізу соціальних ситуацій морально-естетичного характеру, гра-драматизація) забезпечити позитивну мотивацію, сформувати моральну самооцінку;

- організація здоров'язбережувальної роботи студентів передбачає розроблення програм, упровадження в навчальний процес здоров'язбережувальних дисциплін, психолого-педагогічне консультування, фізкультурно-оздоровча робота. Слід зауважити, що робота викладача в цьому напрямку пов'язана з безпосередніми функціональними обов'язками викладача вищої школи. Це, зокрема:

1. Підготовка навчальних курсів здоров'язбережувального спрямування, їх методологічне і методичне забезпечення, вибір засобів інформаційної (аудіо, відео, комп'ютерної, телекомунікаційної) підтримки.

2. Створення навчальних, тренінгових, контрольних програм, спрямованих на забезпечення здорового способу життя.

3. Авторська участь у підготовці навчальної літератури й навчальнометодичних посібників.

4. Читання лекцій, проведення лабораторних, семінарських та інших видів практичних занять, конференцій, рольових ігор тощо.

5. Організаційно-методичне забезпечення практики студентів та участь у іiі проведенні.

6. Пошук i розроблення нових педагогічних методів i освітніх технологій підвищеної ефективності здоров'язбереження.

7. Консультаційна та індивідуальна робота зі студентами із проблем зміцнення та збереження здоров'я молоді.

8. Пошук джерел фінансування наукових досліджень і конкретних практичних розробок.

9. Планування, організація й виконання наукових досліджень із проблем здоров'я та забезпечення здорового способу життя.

10. Реалізація виховних функцій у процесі групової та індивідуальної роботи зі студентами, спрямованої на зміцнення здоров'я молоді, під час неформального спілкування з ними.

11. Неперервне особистісне і професійне зростання, підвищення наукової та педагогічної компетентності і кваліфікації.

12. Організація фізкультурно-оздоровчої роботи.

13. Організація самостійної роботи студентів щодо забезпечення потреби у здоровому способі життя.

Слід зауважити, що важливе значення під час забезпечення здорового способу життя студентської молоді у ВНЗ має організація самостійної роботи студентів, адже вона потребує чітко продуманого організаційно-методичного супроводу з боку викладача. Важливо, щоб викладач не тільки надавав студентам своєчасну допомогу в розв'язанні завдань самостійної роботи, але й сприяв цілеспрямованому формуванню в них знань і вмінь щодо іiі організації. Важливу роль в організації самостійної роботи відіграє професіональний рівень викладача, його самоосвіта, уміння організовувати пошукову діяльність студента, зважаючи на власний досвід 
та настанови. Від цього залежить якість рекомендованої літератури, актуальність тематики рефератів, вибір видів та змісту завдань або проблемних питань.

Викладач формує стиль роботи студентів, їхні переконання. Р. Раєвський зауважує, що в самостійній роботі, спрямованій на забезпечення здорового способу життя, студентів передусім треба «орієнтувати на актуальність, наукову точність, культуру інтерпретації чужих думок та ідей», на вміння аналізувати та робити висновки з прочитаного матеріалу [5, с. 64].

На думку О. Біди, під час організації самостійної роботи, спрямованої на формування потреби студентів у здоровому способі життя, викладач передусім має забезпечити: планування самостійної роботи студентів; організацію самостійної роботи студентів, тобто взаємозв'язок компонентів системи діяльності студентів; керування самостійною роботою студентів з виправлянням помилок та контроль для досягнення мети роботи; передавання інформації, яка допоможе студентові прийняти рішення [1, с. 12].

На етапі планування відбувається надання викладачем допомоги у формуванні мети роботи та проектування студентами ідеального результату власної діяльності. Також викладач визначає, які знання, вміння та навички потрібні для ії виконання. Забезпечення педагогічного супроводу під час проведення самостійної роботи студентів вимагає, зокрема, визначення оптимального взаємовідношення між виконавчою та творчою діяльністю студентів, а також використання різноманітних видів навчальної діяльності, які сприяють розвитку самостійності осіб, які навчаються.

Науковці зазначають, що на цьому етапі викладач має забезпечити добір таких методик і завдань, які б орієнтували студентів на свідоме засвоєння матеріалу та на формування здатності використовувати здобуті знання в подальшому житті.

Важливе місце в організації викладачем самостійної роботи, яка забезпечуватиме потреби студентів у здоровому способі життя, посідає керівництво і контроль за їх діями. Функція контролю має особливе значення, тому що надає можливість робити висновки щодо ефективності роботи студентів. Контроль повинен здійснюватися послідовно, ретельно, а головне - своєчасно. На цьому етапі викладач має заохотити студентів до самостійної діяльності, спрямованої на ведення здорового способу життя, а не примушувати до неї;

- творче використання нетрадиційних засобів оздоровлення передбачає застосування зарубіжних та національних традицій ведення здорового способу життя (аюрведична медицина, гомеопатія, остеопатія і хіропрактика, лікування травами, натуропатія, йога). Завдання викладача в цьому напрямку допомогти студентам отримати певні знання 3 традиційних та нетрадиційних методів оздоровлення, а також навчити студента зберігати здоров'я, тобто володіти основами здоров'язбереження, що $\epsilon$ основою будь-якої професії в сучасних ринкових умовах;

- культивування еталона здорової, гарної, життєздатної особистості передбачає формування самосвідомості студентів щодо важливості здоров'язбереження, ведення здорового способу життя; формування моди на культуру здоров'язбереження, оскільки здоров'я особистості- це засіб їі життєдіяльності, працездатності та дієвості.

Відповідно до напрямів роботи основними завданням викладача вищої школи $€$ : формування світогляду і життєвої позиції студента щодо ведення здорового способу життя; формування дослідницьких і творчих умінь; формування у студентів віри у власні можливості й у реальність професійних досягнень; застосування 
ефективних методів та прийомів для успішного засвоєння необхідних знань, умінь i навичок ведення здорового способу життя; організація індивідуалізованого навчання (робота у групах, індивідуальна робота); організації самонавчання, зокрема підготовка студентів до збереження і зміцнення здоров'я та ведення здорового способу життя.

Російський педагог Р. Раевський, розглядаючи роль викладача в роботі зі студентами, спрямованої на забезпечення потреби студентів у здоровому способі життя, визначає такі функції викладання: 1) аналітико-прогностичну (визначає необхідний обсяг валеологічних знань); 2) проектну (вибір змісту навчання: аудиторні заняття, виконання письмових робіт, виконання різних дослідницьких робіт, самостійне вивчення теми); 3) комунікативну (мотивує, інформує, керує діяльністю студента під час дотримання здорового способу життя); 4) дидактичну (створює необхідний дидактичний матеріал, рекомендації щодо його виконання); 5) контрольно-корегувальну (контроль і корекція рівня знань); 6) психологічної підтримки (консультування, групові тренінги); 7) організаторську (оздоровча робота та робота в таборах) [5, с. 435].

Отже, щоб мати здорове покоління, необхідно ширше та глибше розвивати роботу серед молоді, пов'язану з забезпеченням потреби у здоровому способі життя. Провідна роль у цій роботі належить педагогу, який мотивує, організовує, корегує, пропагує та формує у студентів навички здорового способу життя.

Зважаючи на актуальність проблеми та необхідність їі детального вивчення, у подальшому перспективним уважаємо вивчення шляхів ініціації органами державної влади та місцевого самоврядування різноманітних проектів, спрямованих на поширення здорового способу життя серед молоді.

\section{Література}

1. Біда О. А. Збереження і зміцнення здоров'я студентської молоді в освітньому процесі / О. А. Біда // Вісник Черкаського ун-ту. Серія: Педагогічні науки. - Черкаси, 2012. - № 24 (237). - С. 12-15. 2. Борисов Б. А. Организация и методика проведения практических занятий в вузе по учебной дисциплине «Физическая культура» : [учеб. пособие] / Б. А. Борисов. - Кемерово, 2005. - 453 с. 3. Вольнская Е. В. Воспитание культуры здоровья в профессиональной подготовке студентов педагогического вуза : автореф. дис. на соискание учен. степени канд. пед. наук: спец. 13.00.08 «Теория и методика профессионального образования»/ Е. В. Вольнская. - Тула, 2009. - 22 с. 4. Краснов И. С. Методологические аспекты здорового образа жизни россиян / И.С. Краснов// Физическая культура: воспитание, образование, тренировка. - 2004. - № 2. - С. 61-63. 5. Раевский Р. Т. Здоровье, здоровый и оздоровительный образ жизни студентов / Р. Т. Раевский, С. М. Канишевский; под общ. ред. Р. Т. Раевского. - Одесса : Наука и техника, 2008. - 556 c.

УДК: 005:008: 316

Світлана Яиник

\section{АНТРОПОЛОГІЧНИЙ ПІДХІД ДО УПРАВЛІНСЬКОЇ КУЛЬТУРИ ФАХІВЦІВ СІЛЬСЬКОГОСПОДАРСЬКОЇ ГАЛУЗІ}

Яшник С. В. Антропологічний підхід до управлінської культури фахівців сільськогосподарської галузі.

Аналізується категорія ментальності в аспекті виявлення глибинних феноменів психіки етносів, які регулюють поведінку і спосіб буття особистості у світі. 